\title{
Heavy metals in the air: Analysis using Instrument, air pollution and human health - a review
}

\author{
Siti Noor Syuhada Muhammad Amin a, Azman Azid b, ${ }^{\star}$, Muhamad Shirwan Abdullah Sani c, Ku \\ Mohd Kalkausar Ku Yusof ${ }^{b}$, Mohd Saiful Samsudin ${ }^{b}$, Nurul Latiffah Abd Rani ${ }^{b}$, Saiful Iskandar \\ Khalit $b$
}

\footnotetext{
a Faculty of Health Sciences, Universiti Sultan Zainal Abidin, Gong Badak Campus, 21300 Kuala Nerus, Terengganu, Malaysia

${ }^{b}$ Faculty Bioresources and Food Industry, Universiti Sultan Zainal Abidin, Besut Campus, 22200 Besut, Terengganu, Malaysia

c International Institute for Halal Research and Training, International Islamic University Malaysia, Selangor, Malaysia

* Corresponding author: azmanazid@unisza.edu.my
}

\section{Article history}

Received 9 January 2018

Revised 26 Mac 2018

Accepted 20 May 2018

Published Online 16 December 2018

\begin{abstract}
Air pollution can harm human health, cause-effect to the environment and trigger factor to property damage. Various researches have proven the connection between air quality and human health. The previous research on epidemiology and laboratory studies demonstrated that ambient air pollutants (for example PM, O3, SO2 and NO2) contribute to various respiratory problems including bronchitis, emphysema and asthma. This present mini-review is to discuss the relationship between human health and air quality. This conceptual paper is focusing on the findings from air quality based on literature review and the significant health effects which related to it. Besides, the principle of analytical instrumentation is also being discussed in order to identify the best instrument in laboratory analysis.
\end{abstract}

Keywords: Heavy metal, the principle analysis, human health, toxic, air pollution

\section{INTRODUCTION}

Heavy metals are referred to the metals with the density of at least five times higher than water (Adani et al., 2015; Nagajyoti et al., 2010). In the air, heavy metals can accumulate from the sources such as mining process, fossil fuel's combustion, metallurgical process, incineration activities, industrial plants and windblown soil dust (Adani et al., 2015; Hassanien, 2009; Kampa and Castanas, 2008). Researchers all around the world such as in Brazil (Silvia et al., 2004), Denmark (Karl and Liaquat, 2002), Portugal (Vasconcelos and Tavares, 1997), India (Khillare et al., 2004, Spain (Moreno-Grau et al., 1997; Mateu et al., 1999; Moreno-Grau et al. 2000), Egypt (Abdel-shary et al. 1992), and Russia (Drobyshev and Emelina, 2001) have studied a number of heavy metals. From the findings, several numbers of heavy metals are dangerous and can lead to pollutants in human health and the environment. This will disrupt human's vitality as well.

Heavy metals had a relation with the respirable dust particles. The sizes of heavy metals inside the dust, below than $10 \mu \mathrm{m}$ can merge deeper in lungs, retained inside the lungs and cannot be moved out easily with exhalation and inhalation process which able to harm the human health (Chaudhari et al., 2012; Srivastava and Majumder, 2008; Hsan, 2008). Heavy metals in environmental dust can enter human's tissues and internal organs. This accumulation processes of heavy metals inside a human body are done through respiration, skin contact, ingestion and absorption (Aelion et al., 2008; Ahmed and Ishiga, 2006; De-Miguel et al., 2007; Sezgin et al., 2003). This process will trigger the effects on human health and vitality (Faiz et al., 2009). The concentration of heavy metals in air showed spatial variation. This process occurred due to air and heavy metal's concentration based on distances to the sources and the relative importance of local sources. The concentration levels of heavy metals in the air are influenced by the speed and direction of the wind and seasonal variations (Gharaibeh et al., 2010).

During outdoor activities, people can easily come into contact with airborne metals. The particulate matters are involved in their food and beverages, inhalation of fine particulates and dermal contact with particulate fallout (Bian et al., 2015).

The analysis for dust in the air was conducted by using the aqua regia method described by Radojevic and Bashkin (2006). Aqua regia method is a process of a mixture of nitric acid and hydrochloric acid. They are optimally in a molar ratio of 1:3. This digestion procedure is considered adequate for environmental samples (Chen and Ma, 2001; Vercoutere et al., 1995). Aqua regia digestion (Soon and Abboud, 1993 ) is used widen to determine the contents of heavy metal elements in environmental tasks (Taraškevičius et al., 2013).

Instead of aqua regia digestion method, inductively coupled plasma mass spectrometry (ICPMS) is also classified as one of the techniques used for the analysis of heavy metals. This analysis is 
considered to be the best technique due to its sensitivity, selectivity, reproducibility, wide dynamic concentration range and its low cost (Thomas, 2008). ICPMS is a powerful technique that allowing the multielemental ultra-trace analysis of a wide variety of samples. The spatial variation of heavy metal concentration can be analysed using the advanced statistical technique, named chemometrics.

\section{DIGESTION AND THE PRINCIPLES OF INSTRUMENTATION}

\section{Digestion through aqua regia method}

The samples and heavy metal content for air particulate in the certified standard reference materials (NIST®SRM® 1648a) were digested for elemental analysis. The SRM ${ }^{\circledR} 1648$ a standard was used for checking the quality and accuracy of the quantitative analysis. Digestion samples were conducted using the aqua regia method as described by Radojevic and Bashkin (2006). Aqua regia method is a process of a mixture of nitric acid and hydrochloric acid (Azaman et al., 2015), optimally in a molar ratio of $1: 3$, which is a digestion procedure that considers adequate for environmental samples (Chen and Ma, 2001; Vercoutere et al., 1995). Aqua regia digestion is widely used for the determination of the contents of heavy metal elements to solve environmental tasks (Soon and Abboud, 1993; Taraškevičius et al., 2013).

WhatmanTM filter papers (blank and samples) that have been cut into small pieces and SRM ${ }^{\circledR} 1648$ a were placed into a $100 \mathrm{~mL}$ beaker (separate beaker, respectively) and treated with $50 \mathrm{~mL}$ of aqua regia. The beakers were covered with watch glass during the heating process. The mixture was heated at $140^{\circ} \mathrm{C}$ to near dryness. The samples were filtered off while the beaker rinsed with $10 \% \mathrm{HNO}_{3}$ (Samsudin et al. 2017). These processes were repeated for three times. Then, the solutions were cooled at room temperature, transferred into a $100 \mathrm{~mL}$ volumetric flask and diluted to volume with $10 \% \mathrm{HNO}_{3}$ for the final solution.

\section{The principle of atomic absorption spectroscopy (AAS)}

Atomic Absorption Spectroscopy (AAS) is a technique of measuring quantities of chemical elements. The elements present in environmental samples are measured through absorbed radiation by the chemical element of interest. The atoms absorb ultraviolet or visible light and make transitions to higher energy levels (Fig. 1).

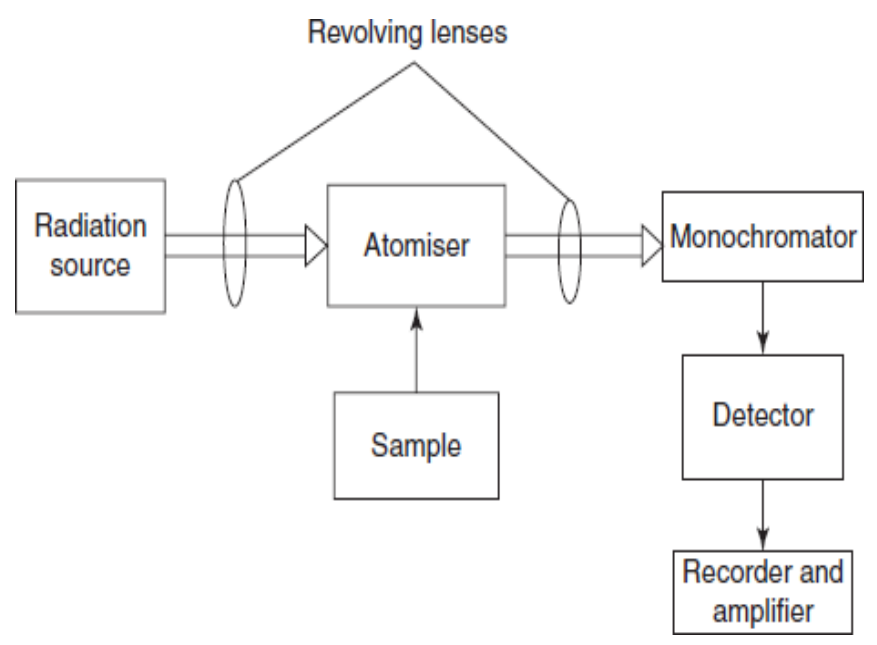

Fig. 1 Atomic absorption Spectroscopy Principle's.

\section{The principle of inductively coupled plasma optical} emission spectrometry (ICPOES)

Inductively Coupled Plasma is one method of optical emission spectrometry. The atoms from the component elements are excited when plasma energy is given to an analysis sample from outside. The emission rays that correspond to the photon wavelength are measured when the excited atoms return to low energy position. The emission rays (spectrum rays) are released. Based on the position of the photon rays, the element type is determined. Based on the rays' intensity, the content of each element is determined. In order to generate plasma, an argon gas is supplied to torch coil and high-frequency electric current is applied to the work coil at the tip of the torch tube. After the electromagnetic field created in the torch tube by the high-frequency current, argon gas is ionized and plasma is generated. This plasma has high electron density and temperature $(10000 \mathrm{~K})$. This energy is used in the excitation-emission of the sample. Solution samples are introduced into the plasma in an atomized state through the narrow tube in the center of the torch tube (Fig. 2).

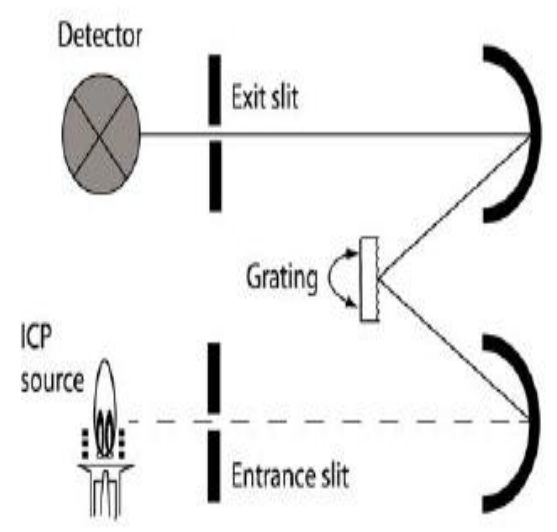

Fig. 2 Inductively coupled plasma optical emission Spectrometry Principle's.

\section{The principle of inductively coupled plasma mass spectrometry (ICPMS)}

The ion source, ICP is an ideal ionization source for mass spectrometry and can ionize over $90 \%$ of many elements. Ions produced in the ICP are led through the sampling interface to the mass analysis unit. The sampling interface unit consists of two metallic cones, the sampling cone and the skimmer cone and a rotary gear pump ventilates between the two into several hundred Pa condition. The path of the ions pulled through by the sampling cone and the skimmer cone converge into the mass spectrophotometer through the ion lens. The ion lens and the mass spectrophotometer unit are ventilated to 10-3 and 10-4 Pa respectively, by the turbo molecular pump. The ions sorted by mass with the mass spectrophotometer are detected by the ion detector (Fig. $3)$.

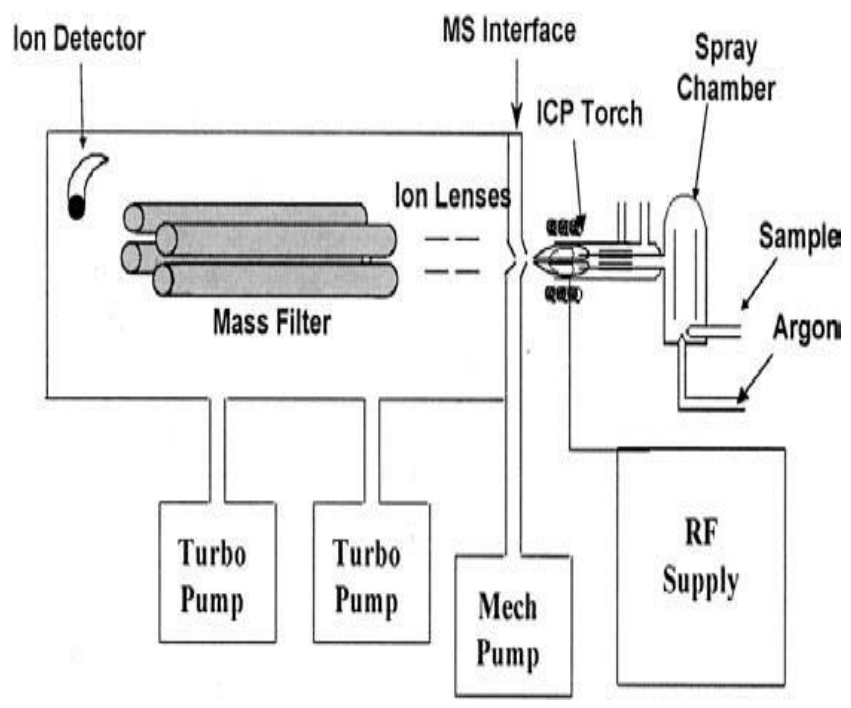

Fig. 3 Inductively coupled plasma mass spectrometry Principle's.

\section{Comparison between analysis by AAS, ICPOES and ICPMS}

Based on the above consideration (Table 1), ICPMS gave the best performance in terms of detection limit, the number of elements involved in one time and the amount of sample usage during detection. However, in order to reduce the cost, analysis by using AAS is recommended. 
Table 1 Comparison of AAS, ICPOES and ICPMS (Tyler and Jobin Yvon, 1995).

\begin{tabular}{lccc}
\hline & AAS & ICPOES & ICPMS \\
\hline Detection limit & Good & Very good & Excellent \\
No. of elements & $>50$ & $>75$ & $>75$ \\
Sample usage & High & Low & Low \\
Skill requirement & Yes & Yes & Yes \\
Operating cost & Low & High & Very high
\end{tabular}

\section{HEAVY METALS, AIR POLLUTION AND HUMAN HEALTH}

\section{Heavy metals and human health}

Heavy metal is divided into two categories, which are essential metals and non-essential metals. Lead $(\mathrm{Pb})$, mercury $(\mathrm{Hg})$ and cadmium (Cd) are categorized as non-essential metals. These heavy metals are clarified as toxic and harmful to organisms, although in a small amount for over a long period of time or in large amount for a short period (Thomas et al., 2009; Zheng et al., 2011). Nickel, copper and manganese are classified as an essential metal. This is due to their important role in the biological process (Fernandes et al., 2008; Stern et al., 2007). The dose-response curve for essential metal is U-shaped. These metals have both effects either deficiency or benefits as well. The excess of copper will produce adverse health (Stern et al., 2007).

Manganese (Mn) is a metal that classified as a metal which involved of low toxicity and effect to organisms. $\mathrm{Mn}$ is considered of having biological significance due to their ability to prevent heart attack, stroke and cardiac arrest. Manganese's deficiency will trigger to congenital malformations in the generation of the population, growth retardation and infertility problems in the reproductive system (Saha and Zaman, 2013). However, at high concentrations of Mn, it will become toxic to organisms. This effect may lead to the neurologic and psychologic problem (Saha and Zaman, 2013; Perl and Olanow, 2007).

Iron $(\mathrm{Fe})$ is a mineral essential for every living cell and necessary for the synthesis of myoglobin, haemoglobin and certain process in human's body. Fe's deficiency will result in weakness, susceptibility and inability to concentrate routinely (Akoto et al., 2014). Anderson and Fitzgerald (2010) studied that one of the most common nutrient deficiencies in the world is Fe deficiency in anaemia. Anaemia is a type of disease that gives poor performance in circulatory transport and also will reduce oxygen supply to muscle and brain (Erdman et al., 2012).

Normally, nickel $(\mathrm{Ni})$ is an essential metal and occurs at very low levels in the environment. However, a deficiency of $\mathrm{Ni}$ in humans has not been clarified yet (Barceloux and Barceloux, 1999). Ni is known to be carcinogenic for organisms (Salnikow and Kasprzak, 2005). Ni can lead to fibrosis, tumours, lung inflammation and emphysema due to its highly concentrations in the surrounding area (Forti et al., 2011).

Chromium (Cr) is also another one type of essential trace element in certain animals and homo sapiens. This heavy metal may reduce body fat in an adipose tissue and also lead to lean body mass improvement. However, their effects are small as compared to those of having a well-balanced diet and doing proper exercise (Tulasi and Rao, 2014; Roussel et al., 2007). In excess amount, it could lead to fatal effect. Lack of $\mathrm{Cr}$ will expose to growth disturbances and reduction in glucose, lipid and protein metabolism (Barceloux and Barceloux, 1999). According to Stipanuk and Caudill (2012), based on metaanalysis, a positive association between $\mathrm{Cr}$ and impaired glucose tolerance are recorded.

Zinc $(\mathrm{Zn})$ is a trace element that has a positive impact on humans and plants. $\mathrm{Zn}$ is known as a cofactor to enzymes that involved in RNA and DNA metabolism. $\mathrm{Zn}$ helps in the structure stabilization in a large number of proteins (Chasapis et al., 2012; Song et al., 2009; Song et al., 2010). Within the large amount, Zn becomes toxic (Krishna et al., 2014). A deficiency of $\mathrm{Zn}$ can lead to several disorders (Stipanuk and Caudill, 2012). The problems happen due to Zn's deficiency are poor pregnancy outcomes (Stipanuk and Caudill, 2012; Chasapis et al., 2012) and development of the cardiovascular disorder (Messner et al., 2009; Afridi et al., 2011) and malignant tumour such as cancer ( Kazi et al., 2010).

Copper $(\mathrm{Cu})$ is an essential metal of enzymes and necessary for the haemoglobin synthesis (Thomas et al., 2009). Impaired delivery of $\mathrm{Cu}$ can result in decreased cuproenzyme activity, the skeletal and vascular systems (Failla et al., 2001). Anaemia, neutropenia and osteoporosis are caused by a lack of copper (Angelova et al., 2011). Accumulation of $\mathrm{Cu}$ can trigger the Mense disease which is classified as one of a fatal disorder (Gu et al., 2002). Wilson disease also could occur due to $\mathrm{Cu}$ accumulates in the brain and eyes in the form of Kayaer-Fleischer ring (Attri et al., 2006; Sarkar, 1999). Kidney damage and even death could happen due to excessive intake of $\mathrm{Cu}$ (Dorsey et al., 2004).

Besides, mercury $(\mathrm{Hg})$ is a non-essential element. In human, $\mathrm{Hg}$ can cause the development of fetus destroyed due to their toxicity and also considered as a carcinogenic (Ikem and Egilla, 2008). While Vettori et al., (2003) studied due to the Hg poisoning, neuronal loss in the cerebellum granule layer and damage of discrete visual cortex area occurs in the adult brain.

$\mathrm{Cd}$ is known as non-essential metal that can cause breast cancer and prostate cancer in humans (Chaudhari et al., 2012). Cd also causes damage in kidney, hypertension, tumours, infertility in the reproductive system and hepatic dysfunction (Chaudhari et al., 2012; Rahman and Islam. 2011; Hao et al., 2013).

In addition, lead $(\mathrm{Pb})$ is a naturally-occurring and industriallyproduced element that is very toxic to the human, especially children (Koyashiki et al., 2010). Pb can be found in the air. The fetal brain presents a greater sensitivity to the toxic effects of $\mathrm{Pb}$ as compared to the mature brain in adults (Schnaas et al., 2006). Umar et al., (2001) stated that symptoms of an anaemic condition, intestinal cramps and fatigue caused by the poisoning of $\mathrm{Pb} . \mathrm{Pb}$ also can cause toxicity to kidney and nerve tissues (García-lestón et al., 2010). Nowadays, Arsenic (As) is widely spread in the environment (Rahman et al., 2012). As is a carcinogen and toxic to the organisms. As also has the probability to destroy communities in ecology (Sadiq et al., 2003). Toxicity of As depends on the speciation (Devesa et al. 2008). Trivalent As (III) has the greatest toxicity. According to ATSDR (2000), mono and dimethyl arsenic have low toxicity.

\section{Air pollution}

The air composition consists of $78.0 \%$ nitrogen, $21.0 \%$ of oxygen and $1.0 \%$ mixture of carbon dioxide, water vapour and small quantities of other gaseous (Ashikin et al., 2014). The atmosphere consists of the troposphere (a dense layer that closest to the Earth), stratosphere (less dense gaseous layer and more distant from the Earth), and the ionosphere (ionized gaseous) (Enger and Smith, 2000).

The atmosphere also contains non-gaseous materials present in the form of solid or liquid particles dispersed into the air, such as aerosols or particulate matter (Kemp, 2004).

Kemp (2004), also stated that they are often regarded as synonymous with air pollution, although the elements involved like dust, smoke and salt particles are regularly produced by a natural process such as volcanic activity. The normal biological processes create and release spores, pollen grains, bacteria, viruses and a variety of other microscopic particles. The atmosphere is very important as it performs several functions that have allowed humans to survive and develop almost anywhere on the earth's surface (Kemp, 2004).

Pollution, an unwanted destruction of the natural environment by human and naturally induced insults, is a problem facing the present world. The number of people is rapidly growing, due to the expansion of the world population. It is accepted that pollution is a problem, not for a specific group but for everyone. Enger and Smith (2000), stated that pollution as something that people produce in large enough quantities that it interferes with our health and vitality as well. The contributing factors toward pollution are the population's size and the development of technology that lead to the methods utilized to develop pollution (Enger and Smith, 2000).

Pollution is a product from the inefficiency of human developed processes. Raw materials extraction, product manufacturing and power necessary for the processes in manufacturing leading to a considerable 
amount of waste (pollution) that is no longer of use (Wagner, 1994). Air pollution is physical or chemical changes brought about by natural processes or human activities that result in air quality degradation (Cunningham et al., 2005). The release of large amounts of smoke and other forms of gaseous waste into the air caused an unhealthy ambient. This is because the pollutants were released faster than they could be absorbed and dispersed by the atmosphere (Enger and Smith, 2000). Dispersion through the air is the fastest way of distribution rather than liquid and solid medium.

Regarding history, people have long recognized the existence of atmospheric pollutants, both natural and anthropogenic effect (Botkin and Keller, 2007). In 1550, Leonardo da Vinci wrote that a blue haze formed from materials emitted into the atmosphere from trees. The air pollution is classified into three types which are named as the Natural Pollutants, Primary Pollutants and Secondary Pollutants. Natural Pollutants are referred to natural phenomena of pollutants that find their way into the atmosphere. Some examples of the natural pollutants are forest fires started by lightning or dispersal of pollen.

These materials can interact with one another in the presence of an energy source to form new secondary air pollutants such as ozone, very reactive materials and natural chemicals in the atmosphere.

\section{CONCLUSION}

In summary, the application of the different analytical technique to perform modern chemical tests for indicating the presence of heavy metals in the air are studied in order to know the better one. On the other hand, people all over the world should have a personal concern on how to reduce and get rid of air pollution in human's biome. Health institutions, public and private organizations must have continuous communication about the risk of air pollution towards human health as well.

\section{ACKNOWLEDGEMENT}

This work is fully supported by the University Research Fund (Grant no.: UniSZA/2016/DPU/01). The authors fully acknowledged Universiti Sultan Zainal Abidin for fund approval and those who are directly or indirectly involved.

\section{REFERENCES}

Aelion, C. M., Davis, H. T., McDermott, S., Lawson, A. B. 2008. Metal concentrations in rural top soil in South Carolina: Potential for human health impact. Science of the Total Environment, 402: 149-156.

Abdel-Shafy, H. I., Hindy, K. T., Abdel-Sabour, M. F. 1992. Heavy metal level in the environmental of Ismailia City, Egypt. Journal of Environmental Studies, 39: 279-289.

Adani, M., Mircea, M., D’Isidoro, M., Costa, M. P., Silibello, C. 2015. Heavy metal modelling study over Italy: Effects of grid resolution, lateral boundary conditions and foreign emissions on air concentrations. Water, Air \& Soil Pollution, 226(46): 1-10.

Afridi, H. I., Kazi, T. G., Kazi, N., Kandhro, G. A., Baig, J. A., Jamali, M. K., Shah, A. Q. 2011. Interactions between cadmium and zinc in the biological samples of Pakistani smokers and nonsmokers cardiovascular disease patients. Biological Trace Element Research, 139: 257-268.

Agency for Toxic Substances and Disease Registry. 2000. Toxicological Profile for Arsenic. Atlanta, GA: US Department of Health and Human Services, Public Health Service.

Ahmed, F., Ishiga, H. 2006. Trace metal concentrations in street dusts of Dhaka city, Bangladesh. Atmospheric Environment, 40(3): 835-3844

Akoto, O., Bismark Eshun, F., Darko, G., Adei, E. 2014. Concentrations and health risk assessments of heavy metals in fish from the Fosu Lagoon International Journal of Environmental Research, 8(2): 403-410.

Anderson, J., Fitzgerald, C. 2010. Iron: An essential nutrient review. [Online] From: http://www.ext.colostate.edu/pubs/foodnut/09356.html. [Acessed on December 2017].

Angelova, M., Asenova, S., Nedkova, V., Koleva-Kolarova, R. 2011. Copper in the human organism. Trakia Journal of Sciences, 9(1): 88-98.

Ashikin, N., Mabahwi, B., Ling, O., Leh, H., Omar, D. 2014. Human health and wellbeing: Human health effect of air pollution. Procedia - Social and Behavioral Sciences, 153: 221-229.
Attri, S., Sharma, N., Jahagirdar, S., Thapa, B. R., Prasad, R. 2006. Erythrocyte metabolism and antioxidant status of patients with Wilson disease with hemolytic anaemia. Pediatric Research, 59(4 Part 1): 593.

Azaman, F., Juahir, H., Yunus, K., Azid, A. Kamarudin, M. K. A., Toriman, M. E. Mustafa, A. D., Amran, M. A., Hasnam, C. N. C., Saudi, A. S. M., 2015. Heavy metal in fish: Analysis and human health - a review. Jurnal Teknologi, 77 (1): 61-69.

Barceloux, D. G., Barceloux, D. (1999). Nickel. Journal of Toxicology: Clinical Toxicology, 37(2): 239-258.

Bian, B., Zhou, L. J., Li, L., Lv, L., Fan, Y.M. 2015. Risk assessment of heavy metals in air, water, vegetables, grains, and related soils irrigated with biogas slurry in Taihu Basin, China. Environmental Science and Pollution Research, 22: 7794-7807.

Botkin, D. B., Keller, E. A. 2007. Environmental science: Earth as a living planet. Hoboken, NJ: Wiley.

Chasapis, C. T., Loutsidou, A., Spiliopoulou, C. A., Stefanidou, M. E. 2012 Zinc and human health: An update. Archives of Toxicology, 86: 521-534.

Chaudhari, P. R., Gupta, R., Gajghate, D. G., Wate, S. R. 2012. Heavy metal pollution of ambient air in Nagpur City. Environmental Monitoring and Assessment, 184:2487-2496.

Chen, M., Ma, L. Q. 2001. Comparison of three aqua regia digestion methods for twenty Florida soils. Soil Science Society of America Journal, 65: 491499.

Cunningham, B., Cunningham, M. A., Saigo, B. W. 2005. Environmental science: A Global Concern (8th ed.). Boston: McGraw Hill.

De-Miguel, E., Iribarren, I., Chaco'n, E., Ordon ez, A., Charlesworth, S. 2007. Risk-based evaluation of the exposure of children to trace elements in playgrounds in Madrid (Spain). Chemosphere, 66: 505-513.

Devesa, V., Velez, D., Montoro, R. 2008. Effect of thermal treatments on arsenic species contents in food. Food and Chemical Toxicology, 46: 1-8.

Dorsey, A., Ingerman, L., Swarts, S. 2004. Toxicological Profile for Copper, Agency for Toxic Substances and Disease Registry, United States Department of Health and Human Services, Atlanta, Georgia.

Drobyshev, A. I., Emelina, O. I. 2001. Analysis of atmospheric aerosols by atomic emission spectroscopy with electrical discharge sampling. Journal of Analytical Chemistry, 56: 577-580.

Enger, E. D., Smith, B. F. 2000. Environmental Science: A Study of Interrelationships (7th Ed.). Boston, Mass: Mcgraw-Hill.

Erdman Jr, J. W., Macdonald, I. A., Zeisel, S. H. (Eds.). 2012. Present Knowledge in Nutrition. 10th edition. A John Wiley \& Sons, Ltd., Publication

Failla, M. L., Johnson, M. A., Prohaska, J. R. 2001. Copper. In: Present Knowledge in Nutrition. Washington D.C.: Life Sciences Institute Press. 373-383.

Faiz, Y., Tufail, M., Javed, M. T., Chaudhry, M. M., Siddique, N. 2009. Road dust pollution of $\mathrm{Cd}, \mathrm{Cu}, \mathrm{Ni}, \mathrm{Pb}$ and $\mathrm{Zn}$ along Islamabad expressway, Pakistan. Microchemical Journal, 92, 186-192.

Fernandes, C., Fontaínhas-Fernandes, A., Cabral, D., Salgado, M. A. 2008 Heavy metals in water, sediment and tissues of Liza saliens from EsmorizParamos Lagoon, Portugal. Environmental Monitoring and Assessment, 136(1-3): 267-75

Forti, E., Salovaara, S., Cetin, Y., Bulgheroni, A., Tessadri, R., Jennings, P., Prieto, P. 2011. In vitro evaluation of the toxicity induced by nickel soluble and particulate forms in human airway epithelial cells. Toxicology in Vitro, 25(2): 454-461

García-lestón, J., Mendez, J., Pásaro, E., Laffon, B. 2010. Author's personal copy genotoxic effects of lead: An updated review. Environment International, 36: 623-636.

Gharaibeh, A. A., El-Rjoob, A.-W. O., Harb, M. K. 2010. Determination of selected heavy metals in air samples from the northern part of Jordan. Environmental Monitoring and Assessment, 160:425-429.

Gu, Y., Kodama, H., Sato, E., Mochizuki, D., Yanagawa, Y., Takayanagi, M., Lee, C. 2002. Prenatal diagnosis of menkes disease by genetic analysis and copper measurement. Brain \& Development, 24: 715-718.

Hao, Y., Chen, L., Zhang, X., Zhang, D., Zhang, X., Yu, Y., Fu, J. 2013. Trace elements in fish from Taihu Lake, China: Levels, associated risks, and trophic transfer. Ecotoxicology and Environmental Safety, 90: 89-97.

Hassanien, M. A. 2009. Atmospheric heavy metals pollution: Exposure and prevention policies in the Mediterranean Basin. In L. I. Simeonov et al. (eds.), Environmental Heavy Metal Pollution and Effects on Child Mental Development: Risk Assessment and Prevention Strategies. Pp. 287-307.

Hsan, G. 2008. The effect of heavy metals on peroxidase from Jerusalem artichoke (Helianthus tuberosus L.) tubers. African Journal of Biotechnology, 7, 2248-2253.

Ikem, A., Egilla, J. 2008. Trace element content of fish feed and Bluegill Sunfish (Lepomis Macrochirus) from aquaculture and wild source in Missouri. Food Chemistry, 110(2): 301-309.

Kampa, M., Castanas, E. 2008. Human health effects of air pollution. Environmental Pollution, 151(2): 362-367. 
Karl, X. Y., Swami, K., Liaquat, H. 2002. Determination of trace 264 metals in atmospheric aerosols with a heavy matrix of cellulose by 265 microwave digestion-inductively coupled plasma mass spectroscopy. Spectrochimica Acta, 57, 73-84.

Kazi, T. G., Wadhwa, S. K., Afridi, H. I., Kazi, N., Kandhro, G. A., Baig, J. A., Arain, M. B. 2010. Interaction of cadmium and zinc in biological samples of smokers and chewing tobacco female mouth cancer patients. Journal of Hazardous Materials, 176: 985-991.

Kemp, D. D. 2004. Exploring environmental issues: An integrated approach. London, United Kingdom: Routledge.

Khillare, P. S., Balachandran, S., Bharat, R. M. 2004. Special and temporal variation of heavy metal in atmospheric aerosol of Delhi. Environmental Monitoring and Assessment, 90: 1-21.

Koyashiki, G. A. K., Paoliello, M. M. B., Tchounwou, P. B. 2010. Lead levels in human milk and children's health risk: A systematic review. Rev Environmrntal Health, 25(3): 243-253.

Krishna, P., Jyothirmayi, V., Madhusudhana Rao, K. 2014. Human health risk assessment of heavy metal accumulation through fish consumption, from Machilipatnam Coast, Andhra Pradesh, India. International Research Journal of Public and Environmental Health, 1(5): 121-125.

Mateu, J., Mirabo, F. B., Forteza, R., Cerda, V., Colom, M., Oms, M. 1999. Heavy metals in the aerosols collected at two stations in Mallorca (Spain). Water, Air, and Soil Pollution, 112: 349-363.

Messner, B., Knoflach, M., Seubert, A., Ritsch, A., Pfaller, K., Henderson, B., Bernhard, D. 2009. Cadmium is a novel and independent risk factor for early atherosclerosis mechanisms and in vivo relevance. Arteriosclerosis, Thrombosis, and Vascular Biology, 1392-1398.

Moreno-Grau, S., Perez-Tornell, A., Moreno-Grau, J., Moreno-Clavel, J. 1997. Determination of lead in aerosol sample collected on glass fiber filters by an improved atomic absorption spectrometry method. Water, Air, and Soil Pollution, 96: 145-153.

Moreno-Grau, S., Tornell, A., Bayo, J., Moreno, J., Angosto, J. M., MorenoClavel, J. 2000. Particulate matter and heavy metals in the atmospheric aerosol from Cartagena, Spain. Atmospheric Environment, 34: 5161-5167.

Nagajyoti, P. C., Lee, K. D., Sreekanth, T. V. M. 2010. Heavy metals, occurrence and toxicity for plants: A review. Environmental Chemistry Letters, 8: 199-216.

Perl, D. P., Olanow, C.W. 2007. The neuropathology of manganese-induced parkinsonism. Journal of Neuropathology \& Experimental Neurology, 66: 675-682.

Radojevic, M., Bashkin, V. N. 2006. Practical Environmental Analysis. London, UK: Royal Society of Chemistry.

Rahman, M., Islam, M. 2010. Adsorption of Cd (II) ions from synthetic waste water using maple sawdust adsorption of Cd (II) ions from synthetic waste water using maple sawdust. Energy Sources, Part A. 32: 222-231.

Rahman, M. S., Molla, A. H., Saha, N., Rahman, A. 2012. Study on heavy metals levels and its risk assessment in some edible fishes from Bangshi River, Savar, Dhaka, Bangladesh. Food Chemistry, 134(4): 1847-1854.

Roussel, A., Andriollo-Sanchez, M., Ferry, M., Bryden, N. A., Anderson, R. A. 2007. Food chromium content, dietary chromium intake and related biological variables in French free-living elderly. British Journal of Nutrition, 98: 326-331.

Sadiq, R., Husain, T., Bose, N., Veitch, B. 2003. Distribution of heavy metals in sediment pore water due to offshore discharges: An ecological risk assessment. Environmental Modelling \& Software, 18: 451-461.

Saha, N., Zaman, M. R. 2013. Evaluation of possible health risks of heavy metals by consumption of foodstuffs available in the central market of Rajshahi City, Bangladesh. Environmental Monitoring and Assessment, 185: $3867-$ 3878 .

Salnikow, K., Kasprzak, K. S. 2005. Ascorbate depletion: A critical step in nickel carcinogenesis? Environmental Health Perspectives, 113(5): 577584.

Samsudin, M. S., Khalit, S. I., Azid, A., Yunus, K., Zaudi, M. A., Badaluddin, N. A., Saudi, A. S. M., 2017. Spatial analysis of heavy metals in mangrove estuary at east coast Peninsular Malaysia: A preliminary study. Journal of Fundamental and Applied Sciences, 9(2): 680-697.

Sarkar, B. 1999. Treatment of Wilson and Menkes Diseases. Chemical Reviews, 99: 2535-2544.
Schnaas, L., Rothenberg, S. J., Flores, M., Martinez, S., Hernandez, C., Osorio, E., Perroni, E. 2006. Reduced intellectual development in children with prenatal lead exposure. Environmental Health Perspectives. 114(5): 791797.

Sezgin, N., Ozcan, H. K., Demir, G., Nemlioglu, S., Bayat, C. 2003. Determination of heavy metal concentrations in street dusts in Istanbul E-5 highway. Environment International, 29: 979 - 985.

Silvia, M. S., Annibal, D. P. N. A. D., Pereira, N., Emmanoel, V. S. F., Martha, T. A. 2004. Short-term and spatial variation of selected metals in the atmosphere of Niteroi City, Brazil. Microchemical Journal, 78, 85-90.

Song, Y., Chung, C. S., Bruno, R. S., Traber, M. G., Brown, K. H., King, J. C., Ho, E. 2009. Dietary zinc restriction and repletion affects DNA integrity in healthy men. The American Journal of Clinical Nutrition, 90: 321-328.

Song, Y., Elias, V., Loban, A., Scrimgeour, A. G., Ho, E. 2010. Marginal zinc deficiency increases oxidative DNA damage in the prostate after chronic exercise. Free Radical Biology and Medicine, 48: 82-88.

Soon, Y. K., Abboud, S. 1993. Cadmium, chromium, nickel. In M. R. Carter (Ed). Soil Sampling and Methods of Analysis. pp. 101-108, Fla, USA: Lewis, Boca Raton.

Srivastava, N. K., Majumder, C. B. 2008. Novel biofiltration methods for the treatment of heavy metals from industrial wastewater. Journal of Hazardous Materials, 151, 1-8.

Stern, B. R., Solioz, M., Krewski, D., Aggett, P., Aw, T.-C., Baker, S., Starr, T. 2007. Copper and human health: Biochemistry, genetics, and strategies for modeling dose-response relationships. Journal of Toxicology and Environmental Health. 10: 157-222.

Stipanuk, M. H., Caudill, M. A. 2012. Biochemical, Physiological, and Molecular Aspects of Human Nutrition. 3rd Edition. Philadelphia: Elsevier Saundre Publishing.

Taraškevičius, R., Zinkutè, R., Stakènienė, R., Radavičius, M. 2013. Case study of the relationship between aqua regia and real total contents of harmful trace elements in some European soils. Journal of Chemistry.

Thomas, L. D. K., Hodgson, S., Nieuwenhuijsen, M., Jarup, L. 2009. Early kidney damage in a population exposed to cadmium and other heavy metals. Environmental Health Perspectives. 117(2): 181-184.

Thomas, R. 2008. Practical Guide to ICP-MS: A Tutorial for Beginners (Second Edition). Boca Raton, Florida: CRC Press.

Tulasi, G., Rao, K. J. 2014. Essentiality of chromium for human health and dietary nutrition. Journal of Entomology and Zoology Studies, 2(1): $107-$ 108.

Tyler, G., Jobin Yvon, S. 1995. ICP-OES, ICP-MS and AAS Techniques Compared. ICP Optical Emission Spectroscopy Technical Note 5. New Jersey: Edison.

Umar A., Umar R., Ahmad M. S. 2001. Hydrogeological and hydrochemical frameworks of regional aquter system in Kali-Ganga Sub-Basin, India. Environmental Geology, 40(4-5): 602-611.

Vasconcelos, M. T. S. D., Tavares, H. M. F. 1997. Atmospheric metal pollution $(\mathrm{Cr}, \mathrm{Cu}, \mathrm{Fe}, \mathrm{Mn}, \mathrm{Ni}, \mathrm{Pb}$ and $\mathrm{Zn})$ in Oporto City derived from results for lowvolume aerosol samplers. The Science of the Total Environment, 212: 1120.

Vercoutere, K., Fortunati, U., Muntau, H., Griepink, B., Maier, E.A. 1995. The certified reference materials CRM 142 R light sandy soil, CRM 143 R sewage sludge-amended soil and CRM145 R sewage sludge for quality control in monitoring environmental and soil pollution. Fresenius' Journal of Analytical Chemistry, 352:197-202.

Vettori, M. V., Alinovi, R., Belletti, S., Goldoni, M., Franchini, I., Multi, A. 2003. In vitro model for the evaluation of the neurotoxicity of methylmercury. Current state of knowledge. La Medicina del Lavoro (MED $L A V)$. 94-183.

Wagner, T. 1994. In our backyard: A guide to understanding pollution and its effects. New York: Van Nostrand Reinhold.

Zheng, G., Tian, L., Liang, Y., Broberg, K., Lei, L., Guo, W., Nilsson, J., Bergdahl, I. A., Skerfving, S., Jin, T. 2011. $\delta$-Aminolevulinic acid dehydratase genotype predicts toxic effects of lead on workers' peripheral nervous system. Neurotoxicology, 32: 374-382. 
Amin et al. / Malaysian Journal of Fundamental and Applied Sciences Vol. 14, No. 4 (2018) 490-494 